\section{Thought: a different perspective}

SIR - Patricia Churchland's review of Steven Pinker's latest book The Stuff of Thought ('Poetry in motion' Nature 450, 29-30; 2007) offers scant information about the book, and what there is is incorrect. Churchland instead presents her own views on how molecular biology and neurobiology provide challenges to Pinker, but in so doing she undermines the successes of these disciplines. She concludes that Pinker's book is only about semantics and that his discussion of the mind represents a kind of madman nativist perspective, ignoring the role of the environment and research in the neurosciences.

I have the impression that Churchland restricted her reading to the prologue, heaving the book across the room in dismay while ejaculating "Same old, same old!" Otherwise, she would surely have come across Pinker's detailed analysis of the evolution and development of the core conceptual structures of space, time, number and cause, and how these buildingblocks enable the child to acquire not only a lexicon, but also an understanding of the world. This view doesn't eliminate either experience or cultural processes, but rather shows ways in which a core architecture may constrain the acquisition of knowledge and lead to a suite of shared mental capacities.

She would also have come across rich and entertaining chapters on naming our children, swearing (I refrain), and the pragmatics of bargains, bribes and other social conventions. And throughout, Pinker mentions work in the neurosciences. This includes studies of people with brain damage, cellular recordings of animals and humans, and imaging experiments; some of these Pinker conducted himself with colleagues and students.

But these ideas are sometimes controversial, and it saddened me that the Book Review did not discuss why. Instead, it went into challenges apparently posed by genetics and neurobiology for the cognitive sciences, and particularly for the brain-as-merelyhardware kind that Pinker is said to peddle.

Take, for example, Churchland's assertion that "extravagant claims about human uniqueness must deal with the discovery that humans have only about 28,000 genes, and differ from mice in just 300 or so". (Not so: humans have only about 300 genes not found in mice, but the others aren't identical.) Even if accurate, this would not constitute an argument against any of Pinker's book. In fact, it shows why one has to be careful in interpreting the relationship between genomic sequence overlap and phenotypic similarity. The monumental cognitive gap between mice and humans tells us that the number of homologous genes and the percentage of sequence overlap are simplistic measures of species similarity, rather than the genomic overlap telling us that humans are cognitively equivalent to mice.

We have to look to another story to explain how, given such overlap, we are so different. The point is magnified when we consider the $98 \%$ overlap with chimpanzees, and again, the spectacular differences in our cognitive abilities, ranging from the expression of language, music and mathematics, to the creation of soufflés, Global Positioning System navigators and humour. I hope the readers of Nature will dig into Pinker's book, even if it is only to learn what he said.

Marc D. Hauser

Department of Psychology, Harvard University, 33 Kirkland Street, Cambridge,

Massachusetts 02138, USA

\section{Thought: book review has my ideas back to front}

SIR - Patricia Churchland's review of my book The Stuff of Thought ('Poetry in motion' Nature 450, 29-30; 2007) says virtually nothing about the book's contents, and gets two of its main claims backwards. A lengthy section of the book argues against the idea that "thought is like external language in all important respects." And the theory of Jerry Fodor's that Churchland calls "font-change semantics" (whereby a person's knowledge of the meaning of a word, such as cut, consists of a single mental symbol, such as 'cut') is one that I argue against, together with Fodor's innateness ad libitum claim, also mistakenly attributed to me.

The book apparently stimulated the reviewer to free-associate to her own beliefs that psychological phenomena can be explained at the level of neurons and that human thinking is in the service of motor control. The fact that I (like most cognitive psychologists) have not signed up to these views is the only point of contact between my book and her review.

Steven Pinker

Department of Psychology, Harvard University, 33 Kirkland Street, Cambridge,

Massachusetts 02138, USA

\section{Chance to learn and teach in the developing world}

SIR - As married academics on sabbatical leave from the University of California, Davis, we would like to add some comments to your Naturejobs feature on the subject ('The seven-year itch' Nature 448, 834-835; 2007). We felt that you overlooked the importance of academics being role models for people in the developing world, where education is often less than perfect, and meeting the challenge of solving problems in the developing world, where medical, poverty and conservation issues often reach their zenith.

We have moved from California to Dar es Salaam, Tanzania, for our sabbaticals. Here we can interact with Tanzanian academics, work with local non-governmental organizations, use the Internet to write a book, and continue our field work. We hope to expand our intellectual horizons and those of Tanzanian colleagues, and perhaps bring fresh perspectives to developing-world problems. Broadening academic influence outside first-world universities is an important social responsibility. We urge other sabbatical wannabes to take up similar challenges and opportunities.

Tim Caro ${ }^{\star}$, Monique Borgerhoff Mulder $r$

*Department of Wildlife, Fish and Conservation

Biology, University of California, Davis,

†Department of Anthropology,

University of California, Davis,

California 95616, USA

\section{Few women join ranks of Germany's academic élite}

SIR - The excellence initiative is indeed a welcome addition to the German academic world, as your Naturejobs Feature 'Allowing an élite' points out (Nature 450, 452-453; 2007). But you omit to mention the plight of women academics. Only $10 \%$ of full professors at German universities are female. Just $14.6 \%$ of all grants from the DFG, Germany's main funding agency for university research, were awarded to women in 2006, a mere $2 \%$ rise since 2003.

I would be interested to know how many women received financial 'excellence cluster' awards, and whether the DFG is making attempts to reward female scientists in Germany's male-dominated academia. The Feature, whose interviewees and examples were all male, conveys the impression that this will continue to be a man's world.

Laura Niven

Department of Human Evolution,

Max Planck Institute for Evolutionary

Anthropology, 04103 Leipzig, Germany

The German government is keen to increase the number of female scientists in top positions. On 19 November, the federal science minister and the Länder (state) governments agreed on a $€ 75$-million (US\$111-million) programme for creating 200 new tenured positions for female university professors in the next five years - Editor, Nature.

Contributions to Correspondence may be submitted to correspondence@nature.com. 